\title{
Reproductive adaptations in two Palaemon prawn species with differing habitat requirements
}

\author{
Anders Berglund \\ Department of Zoology, P.O. Box 561, S-751 22 Uppsala, Sweden
}

\begin{abstract}
Reproductive adaptations in 2 littoral prawns - Palaemon adspersus Rathke and $P$. squilla (L.) - were investigated in a non-tidal sympatric site in Sweden. The larger sized $P$. adspersus, a habitat specialist living in less fluctuating environments than does $P$. squilla, had a smaller reproductive effort, fewer but larger offspring, fewer clutches per year and reproduced later in life. These findings agree with predictions from $\mathrm{r}$ - and $\mathrm{K}$-selection models. Emphasis is put on the necessity of including nonbreeding females in the calculations of average expected reproductive effort, as this category is shown to influence results substantially. Differences in reproductive adaptations between $P$. squilla populations from the non-tidal Swedish site and 2 tidal-affected sites were analysed. In one tidal-affected site $P$. squilla inhabited the intertidal Fucus zone; in the other it was displaced from this zone into intertidal rockpools by a third, larger species. In both tidal sites eggs were heavier than in, but reproductive effort equal to, the non-tidal Swedish site. In the rockpool site, however, eggs were lighter and reproductive effort less than in the Fucus site, indicating adverse effects on reproduction by the habitat displacement.
\end{abstract}

\section{INTRODUCTION}

The theory of $\mathrm{r}$ - and K-selection predicts that animals living in fluctuating environments should evolve a combination of earlier maturity, smaller offspring, larger numbers of offspring and higher reproductive effort than animals living in more constant environments (MacArthur and Wilson, 1967; Pianka, 1970). This hypothesis has been much criticized on theoretical grounds (for reviews, see Stearns, 1976, 1977, 1980) and has also been repeatedly refuted when applied to marine environments. Thus, tropical marine invertebrates have higher reproductive potentials than those of temperate latitudes (Valentine and Ayala, 1978), and the fecundity of the temperate, brooding seastar Leptasterias hexactis is reduced by increased densityindependent mortality (Menge, 1974).

Another model of a stochastic nature holds that the patterns associated with constant and fluctuating environments described above will be reversed when juvenile mortality fluctuates more than adult mortality (Murphy, 1968; Schaffer, 1974).

The 2 littoral prawns Palaemon adspersus Rathke and $P$. squilla (L.) both have planktonic larvae, which means that the energy content per offspring is relatively low and that the probability of juvenile survival is lower than among organisms with direct development (Christiansen and Fenchel, 1979). Therefore, mortality of larvae ought to fluctuate more than that of adults due to high and fluctuating death rates during the planktonic stage.

In Sweden the 2 prawn species coexist in Zostera marina (L.) meadows. P. squilla also inhabits shallow bare sand bottoms, shallow brown algae belts and rockpools (Berglund, 1980). The latter habitats are characterized by more fluctuating environmental factors, e.g, temperature, salinity and oxygen, than the deeper Zostera meadows (Berglund and Bengtsson, 1981). In French tidal-affected areas $P$. squilla inhabits the intertidal zone (brown algae belts and tidal rockpools; Berglund, 1982).

The deterministic $\mathrm{r} / \mathrm{K}$-selection model predicts that Palaemon squilla should mature earlier, have larger broods, produce smaller offspring and make a greater reproductive effort than $P$. adspersus. The stochastic model predicts the reverse. The aim of this paper is to see which of the 2 models describes best the reproductive strategies of these prawns. Interspecific comparison between $P$. adspersus and $P$. squilla is done on samples from Kilviken Bay, Sweden. Reproductive effort is estimated as RE = dry weight of clutch/dry weight of body. Such ratios are calculated for each 
female, and then similar-aged $P$. adspersus and $P$. squilla are compared with a median test. The most common way to make such comparisons is to calculate the RE-ratios on berried females only. However, if in one species females postpone their reproduction to a large extent until their second year, such a ratio would overestimate the average female's expectancy of RE during her first year. I shall demonstrate how the outcome of interspecific comparison in Kilviken Bay will be exactly reversed when the non-reproducing proportion of females is included in the analysis. Therefore, the proportion of non-reproducing $(\mathrm{RE}=0$ ) females must always be included when RE ratios from different species or populations are compared. An assumption underlying the validity of these calculations is that the average reproductive effort of a population at one time estimates average reproductive effort of an individual female during many reproductive cycles. Finally, the way RE varies with age and with presence/absence of tides will be investigated.

\section{MATERIAL AND METHODS}

Field data were collected in 1981 and 1982 in Kilviken Bay, Fiskebäckskil, at the Swedish west coast $\left(58^{\circ} 15^{\prime} \mathrm{N}\right.$, $\left.11^{\circ} 28^{\prime} \mathrm{E}\right)$, and in July 1981 in Golfe du Morbihan in Bretagne $\left(47^{\circ} 35^{\prime} \mathrm{N}, 2^{\circ} 44^{\prime} \mathrm{W}\right)$ and Pouldohan Bay near Concarneau, also in Bretagne $\left(47^{\circ} 57^{\prime} \mathrm{N}, 3^{\circ} 54^{\prime} \mathrm{W}\right)$.

Kilviken Bay and Golfe du Morbihan are sheltered bays with estuarine salinities (15 to 30 and 22 to $35 \%$ respectively). Both bays are lined with brown algae belts (much more extensive in Golfe du Morbihan due to the great tidal range, 2.5 to $4 \mathrm{~m}$ ), and Zostera grows at depths of ca. 0.5 to $6 \mathrm{~m}$. Pouldohan Bay has oceanic salinity $(35.5 \%$ ), extensive brown algae belts and tidal rockpools are common here. Golfe du Morbihan and Pouldohan Bay are both regarded as 'tidal sites' (tidal range $>2.5 \mathrm{~m}$ ) and Kilviken Bay as a 'non-tidal site' (range $<0.5 \mathrm{~m}$ ). Consult Berglund (1982) for a more detailed description of sampling sites.

In Zostera meadows deeper than $1 \mathrm{~m}$ prawns were captured with a beam trawl (mesh size $2 \mathrm{~mm}$ ). Handnets were used in Fucus belts (mesh size $10 \mathrm{~mm}$ ) and in rockpools (mesh size $2 \mathrm{~mm}$ ). As the smallest females were larger than $20 \mathrm{~mm}$ the sampling methods were probably not size selective. Prawns were preserved in $70 \%$ ethanol immediatly after capture. Females having lost part of their clutch were not included in the analyses.

Length was measured from the base of the eyestalks to the posterior edge of telson. Sex was determined on the basis of presence (males) or absence (females) of a salient process between the third pair of pereiopods, or by presence of the appendix masculina. Age was determined from size classes in length-frequency diagrams (Höglund, 1943; Forster, 1951; Jensen, 1958; Berglund, 1981). Reproductive status was classified in terms of: (a) ripe ovary (well developed and blackened on living prawns); (b) berried (external eggs under abdomen); (c) newly hatched eggs (typical empty space under abdomen); (d) (a) and (b) combined; (e) (a) and (c) combined. The number of eggs of each female from the 1981 samples was counted, and dry body weight $\left(105^{\circ} \mathrm{C}\right.$ for $\left.24 \mathrm{~h}\right)$ and dry clutch weight (total egg weight) were measured. Regressions were compared according to Zar (1974). All test probabilities given are two-tailed. Altogether 317 prawns were measured in this way.

\section{RESULTS}

\section{Interspecific comparisons in Kilviken Bay}

The size-specific number of eggs differed between the species when number of eggs was plotted against body dry weight (Fig. 1). Palaemon squilla carried

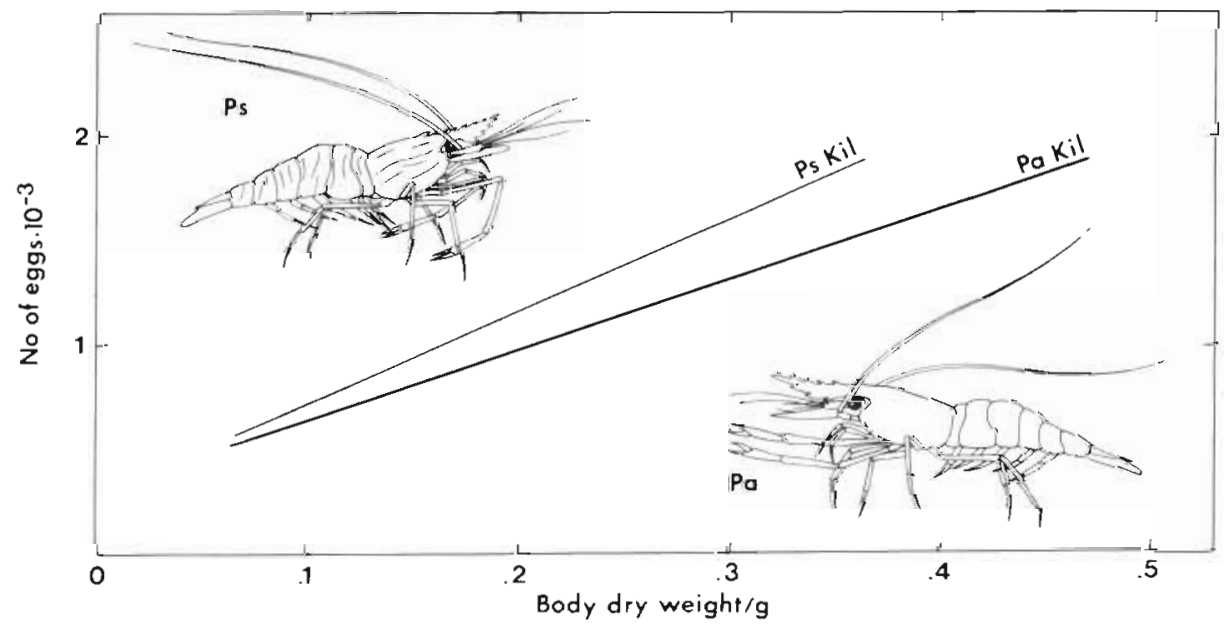

Fig. 1. Number of eggs increase with increasing body weight in both Palaemon species. Both regressions are significant $(P<0.001)$. Samples are from Kilviken Bay (1981; 06.30 to 07.01). Pa: $P$. adspersus, $\mathrm{PS}$ : P. squilla 
Table 1. Interspecific comparisons of numbers of Palaemon females from Kilviken Bay in reproductive ( $\mathrm{r}$ ) and non-reproductive (n) modes. Samples are divided into 1 yr old (1) and 2 yr old (2) prawns. Pa: P. adspersus, Ps: P. squilla

\begin{tabular}{|c|c|c|c|c|c|c|}
\hline Sampling time & Age & Species & $\mathrm{n}$ & r & $\chi^{2}$ & $P \leq$ \\
\hline \multirow[t]{4}{*}{$1981 ; 06.30-07.01$} & 1 & Ps & 0 & 89 & & \\
\hline & 1 & $\mathrm{~Pa}$ & 64 & 86 & 49.71 & .001 \\
\hline & 2 & Ps & 0 & 16 & & \\
\hline & 2 & $\mathrm{~Pa}$ & 1 & 28 & - & $644^{\circ}$ \\
\hline \multirow[t]{4}{*}{$1982 ; 06.12$} & 1 & Ps & 0 & 60 & & \\
\hline & 1 & $\mathrm{~Pa}$ & 127 & 15 & 140.7 & .001 \\
\hline & 2 & Ps & 0 & 25 & & \\
\hline & 2 & $\mathrm{~Pa}$ & 20 & 203 & - & $.109^{\circ}$ \\
\hline \multirow[t]{4}{*}{$1982 ; 06.21$} & 1 & Ps & 0 & 37 & & \\
\hline & 1 & $\mathrm{~Pa}$ & 120 & 35 & 73.12 & .001 \\
\hline & 2 & Ps & 0 & 10 & & \\
\hline & 2 & $\mathrm{~Pa}$ & 14 & 135 & - & $387^{\circ}$ \\
\hline \multirow[t]{4}{*}{$1982 ; 07.01$} & 1 & Ps & 0 & 18 & & \\
\hline & 1 & $\mathrm{~Pa}$ & 70 & 44 & 21.13 & .001 \\
\hline & 2 & Ps & 0 & 14 & & \\
\hline & 2 & $\mathrm{~Pa}$ & 6 & 105 & - & $.483^{\circ}$ \\
\hline
\end{tabular}

more eggs for a given size than $P$. adspersus, and interspecific differences increased with increasing body weight. The regressions had slopes significantly different between the species $(t=4.85, D F=81$, $\mathrm{P}<0.001$ ). The weight of $1 \mathrm{egg}$ also differed between the species. If the average egg weight of 1 female is calculated as dry weight of entire clutch/number of eggs, a median test can be used for detecting differences in egg weights between the species. This test demonstrated that $P$. adspersus produced heavier eggs than $P$. squilla (1981: $\chi^{2}=46.0, P<0.001$ ). Mean egg dry weight $\pm S$. D. was $48.03 \pm 6.30 \mu \mathrm{g}(\mathrm{n}=35)$ in $P$. adspersus and $31.19 \pm 5.94 \mu \mathrm{g}(\mathrm{n}=51)$ in $P$. squilla.

If females with ripe ovaries, berried females, females with newly hatched clutch or, finally, any combination of these states, are considered as 'reproductive', and females not being in any of these states as 'non-reproductive', their respective proportions can be compared. If samples are divided into 1 and 2 yr old females (Table 1), 1 yr old Palaemon squilla in a reproductive state were more frequent than 1 yr old $P$. adspersus. No interspecific differences in Kilviken Bay between 2 yr old females could be established.

When reproductive effort is compared between the 2 species in Kilviken Bay $(1981 ; 06.30$ to 07.01) we find that results differ very much depending on whether non-reproductive females are included in the analysis or not (Table 2). When they are not included, both 1 and 2 yr old Palaemon adspersus had a higher RE than corresponding $P$. squilla year classes. With the refined

Table 2. Interspecific comparisons of reproductive effort (RE) in Palaemon adspersus (Pa) and P. squilla (Ps) from Kilviken Bay (1981; 06.30 to 07.01$)$. Numbers of prawns above or below the median RE ratio

\begin{tabular}{|c|c|c|c|c|c|c|}
\hline $\begin{array}{l}\text { Non-reproducing } \\
\text { females included }\end{array}$ & Age & Median & \multicolumn{2}{|c|}{ Numbers of } & $\chi^{2}$ & $\mathrm{P}<$ \\
\hline \multirow[t]{2}{*}{ No. } & 1 & $\begin{array}{l}0.281< \\
0.281 \geq\end{array}$ & $\begin{array}{r}20 \\
3\end{array}$ & $\begin{array}{l}10 \\
24\end{array}$ & 16.0 & .001 \\
\hline & 2 & $\begin{array}{l}0.179< \\
0.179 \geq\end{array}$ & $\begin{array}{r}12 \\
3\end{array}$ & $\begin{array}{r}3 \\
11\end{array}$ & 7.741 & .01 \\
\hline \multirow[t]{2}{*}{ Yes } & 1 & $\begin{array}{l}0< \\
0=\end{array}$ & $\begin{array}{r}23 \\
105\end{array}$ & $\begin{array}{r}34 \\
4\end{array}$ & 63.3 & .001 \\
\hline & 2 & $\begin{array}{l}0.156< \\
0.156 \geq\end{array}$ & $\begin{array}{r}14 \\
9\end{array}$ & $\begin{array}{l}8 \\
7\end{array}$ & 0.015 & n. s. \\
\hline
\end{tabular}


analysis, including non-reproducing females, the result is reversed: 1 yr old $P$. squilla had a higher RE than 1 yr old $P$. adspersus, while no difference was evident between 2 yr old females. Therefore, primarily the proportion of non-reproducing females determines the RE of 1 yr old prawns, and clutch weight is clearly of secondary importance in this case. Therefore nonreproducing females will be included in all comparisons of RE in this paper.

Another factor capable of altering the picture of reproductive effort is number of clutches per year. An estimate of this number is the proportion of females with external eggs only or a newly hatched clutch, i.e. 1 clutch per female, to number of females with external and internal eggs or with internal eggs and a newly hatched clutch, i.e. 2 simultaneously carried clutches per female. Prawns with intemal eggs only are excluded from this analysis as they may lay 1 or 2 clutches. This ratio may underestimate the true number of twice-breeders (Höglund, 1943), but hopefully the error is about the same in both species. When 1 yr old prawns from 1981 in Kilviken Bay were compared, the proportion of twice-breeders was higher in Palaemon squilla than in P. adspersus (Table 3 ). Between 2 yr old prawns in Kilviken Bay no significant differences emerged, nor did any significant differences persist in Kilviken Bay in 1982, regardless of sample time or age. However, the 1982 sample sizes were generally too small to yield reliable estimates.
Thus, Palaemon squilla starts reproducing earlier and lays more clutches per unit of time than does $P$. adspersus.

\section{Intraspecific comparisons of age classes in Kilviken Bay}

When reproductive/non-reproductive states are compared intraspecifically we find no difference between 1 and 2 yr old Palaemon squilla, while such a difference is pronounced in $P$. adspersus: $1 \mathrm{yr}$ old females were less often in a reproductive mode than were 2 yr old fernales (Table 4). Thus $P$. adspersus reproduces at an older age than $P$. squilla, a result that also is apparent in Fig. 2.

When RE in different age classes are compared, again we find no difference between 1 and 2 yr oid Palaemon squilla, while $P$. adspersus year classes differ substantially in this respect (Table 5).

Intraspecific comparisons yield no significant difference between 1 and 2 yr old Palaemon squilla with regard to clutch numbers (Table 6), while 2 yr old $P$. adspersus had a significantly higher proportion of twice-breeders than did one year old prawns. In June, 1982, however, both species had more twice-breeders in the older year class. On July 1 the same year, again there was no difference between $P$. squilla year class-

Table 3. Interspecific comparisons of number of clutches per season in Palaemon adspersus (Pa) and P. squilla (Ps) sampled in Kilviken Bay. Median tests used

\begin{tabular}{|c|c|c|c|c|c|c|}
\hline Sample & Age & $\begin{array}{l}\text { Number of } \\
\text { clutches }\end{array}$ & \multicolumn{2}{|c|}{ Numbers of } & $\chi^{2}$ & $P \leq$ \\
\hline \multirow[t]{4}{*}{$1981 ; 06.30-07.01$} & 1 & 1 & 24 & 23 & & \\
\hline & & 2 & 58 & 2 & 28.1 & .001 \\
\hline & 2 & 1 & 2 & 6 & & \\
\hline & & 2 & 13 & 21 & 0.1 & n.s. \\
\hline \multirow[t]{4}{*}{$1982 ; 06.12$} & 1 & 1 & 13 & 1 & & \\
\hline & & 2 & 7 & 0 & - & .667 \\
\hline & 2 & 1 & 2 & 44 & & \\
\hline & & 2 & 20 & 125 & 2.2 & n.s. \\
\hline \multirow[t]{4}{*}{$1982 ; 06.21$} & 1 & 1 & 5 & 4 & & \\
\hline & & 2 & 6 & 0 & - & $.092^{*}$ \\
\hline & 2 & 1 & 0 & 25 & & \\
\hline & & 2 & 10 & 89 & - & $.096^{\circ}$ \\
\hline \multirow[t]{4}{*}{$1982 ; 07.01$} & 1 & 1 & 3 & 5 & & \\
\hline & & 2 & 8 & 7 & 0.1 & n.s. \\
\hline & 2 & 1 & 0 & 7 & & \\
\hline & & 2 & 14 & 95 & - & $.396^{\circ}$ \\
\hline
\end{tabular}


Table 4. Intraspecific comparisons of numbers of Palaemon females in reproductive ( $r$ ) or non-reproductive (n) modes. Pa: $P$. adspersus, Ps: $P$. squilla

\begin{tabular}{|c|c|c|c|c|c|c|}
\hline Species & Sample (Kilviken Bay) & Age & $\mathrm{n}$ & $\mathrm{r}$ & $\chi^{2}$ & $\mathrm{P}<$ \\
\hline \multirow[t]{8}{*}{ Ps } & $1981 ; 06.30-07.01$ & 1 & 0 & 89 & & \\
\hline & & 2 & 0 & 16 & 0 & n.s. \\
\hline & $1982 ; 06.12$ & 1 & 0 & 60 & & \\
\hline & & 2 & 0 & 25 & 0 & n.s. \\
\hline & $1982 ; 06.21$ & 1 & 0 & 37 & & \\
\hline & & 2 & 0 & 10 & 0 & n.s. \\
\hline & $1982 ; 07.01$ & 1 & 0 & 18 & & \\
\hline & & 2 & 0 & 14 & 0 & n.s. \\
\hline \multirow[t]{8}{*}{$\mathrm{Pa}$} & $1981 ; 06.30-07.01$ & 1 & 64 & 86 & & \\
\hline & & 2 & 1 & 28 & 14.5 & .001 \\
\hline & $1982 ; 06.12$ & 1 & 127 & 15 & & \\
\hline & & 2 & 20 & 203 & 230.2 & .001 \\
\hline & $1982 ; 06.21$ & 1 & 120 & 35 & & \\
\hline & & 2 & 14 & 135 & 139.9 & .001 \\
\hline & $1982 ; 07.01$ & 1 & 70 & 44 & & \\
\hline & & 2 & 6 & 105 & 76.4 & .001 \\
\hline
\end{tabular}

es, while older $P$. adspersus more often were twicebreeders. The sample from June 12 was too small to be included in this analysis.

\section{Intraspecific comparisons of Palaemon squilla}

In both tidal sites, i.e. Golfe du Morbihan (1981; 07.11 to 18$)$ and Pouldohan Bay $(1981 ; 07.22$ to 24$)$, Palaemon squilla produced heavier eggs than in the non-tidal site, i.e. Kilviken Bay $(1981 ; 06.30$ to 07.01) $\left(\chi^{2}=17.8, \mathrm{P}<0.001\right.$ and $\chi^{2}=3.93, \mathrm{P}<0.05$, respectively). When comparing the 2 tidal sites, $P$. squilla in Golfe du Morbihan (where it occurs in the intertidal Fucus zone) produced heavier eggs than conspecifics in Pouldohan Bay (where it is found in tidal rockpools) $\left(\chi^{2}=13.8, \mathrm{P}<0.001\right)$. However, there was no difference in number of eggs carried by females from the different sites (regressions of numbers of eggs to dry body weight compared, $\mathrm{P}>0.05$ ).

When RE from the 3 sites are compared, I find no differences between Kilviken Bay (1981; 06.30 to $07.01)$ and Golfe du Morbihan (1981; 07.11 to 18$)\left(\chi^{2}=\right.$ 1.16 , n.s.) or between Kilviken Bay and Poldohan Bay $(1981 ; 07.22$ to 24$)\left(\chi^{2}=0.01\right.$, n.s. $)$. However, in the intertidal Fucus site (Golfe du Morbihan) RE was higher than in the rockpool site (Pouldohan Bay) $\left(\chi^{2}=\right.$ 6.622, $P<0.025)$. From all sites similar-sized females ( 27 to $38 \mathrm{~mm}$ length) were employed in the analyses. These females were all 1 yr of age.
Fig. 2. Berried females as $\%$ of total number of females in samples from Kilviken Bay 1982. Pa 1: 1 yr old Palaemon adspersus; $\mathrm{Pa} 2: 2$ yт old $P$. adspersus; Ps 1: 1 YT old $P$. squilla; Ps 2: 2 yr old $P$. squilla. A total of 2,730 females were sampled

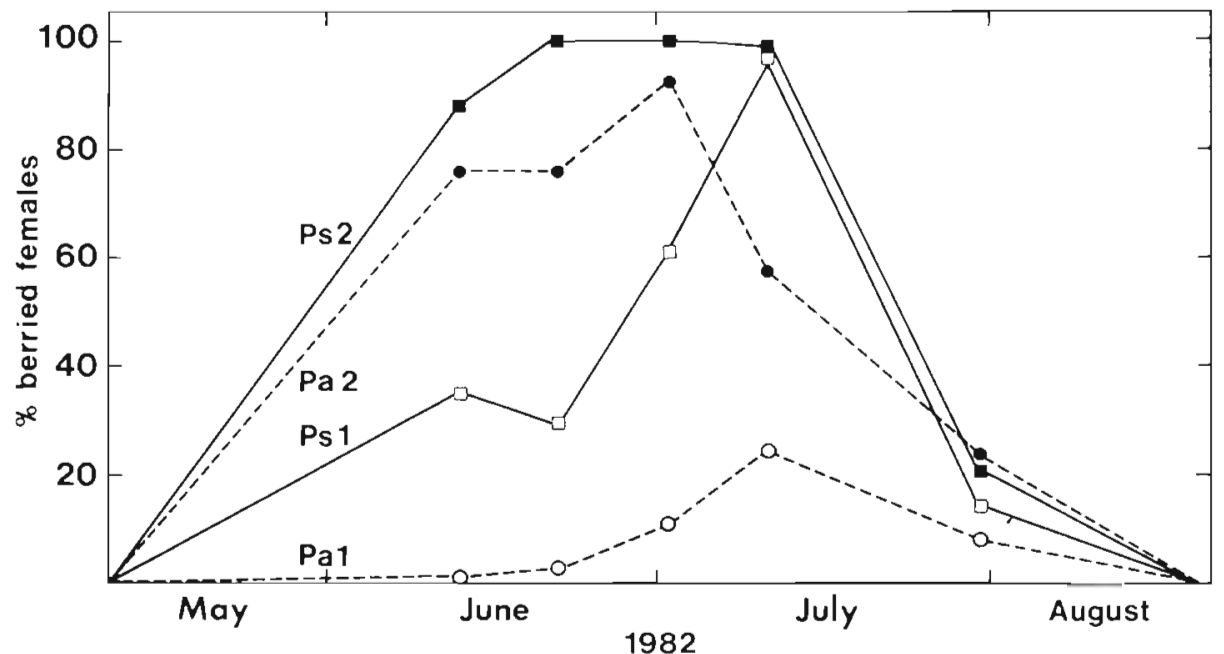


Table 5. Intraspecific comparisons of reproductive effort (RE) between different age classes of Palaemon adspersus ( $\mathrm{Pa}$ ) and P. squilla (Ps) from Kilviken Bay (1981; 06.30 to 07.01). Numbers of prawns above or below the median RE ratio

\begin{tabular}{|clrrrrl|}
\hline Species & Median & Age 1 & Age 2 & $\chi^{2}$ & P $<$ \\
\hline \multirow{2}{*}{ Pa } & $0 \quad<$ & 23 & 15 & & \\
& 0 & $=$ & 105 & 8 & 20.7 & .001 \\
Ps & $0.173<$ & 21 & 5 & & \\
& $0.173 \geq$ & 17 & 10 & 1.285 & n.s. \\
\hline
\end{tabular}

\section{DISCUSSION AND CONCLUSIONS}

Some ambiguities are inherent in the above data. First, I assume that the energy content/weight ratios in eggs and prawns do not differ between species or sites under comparison. As differences in reproductive effort and other traits considered here generally are quite large, such ratios would have to differ by unrealistic amounts in order to alter the conclusions.

Second, there are several possible errors in measurements of number of clutches (Höglund, 1943; Jensen, 1958 ) but they probably affect both species alike. As Palaemon squilla generally had more clutches (at least 1 yr old prawns) per season than $P$. adspersus, this fact only strengthens the point that $P$. squilla makes a higher reproductive effort.

Third, hybridization may have, if it occurs, lowered reproductive effort in sympatric populations in Kilviken Bay if hybrids are less fecund. Therefore, I carried out hybridization experiments with different sex/ species combinations. In controls all females retained their roe (20 Palaemon adspersus and 11 P. squilla pairs), while in 'mixed' couples all females lost their clutches ( $8 P$. adspersus male $+P$. squilla female pairs and $14 P$. squilla male $+P$. adspersus female pairs). Thus, hybridization can be discounted as a factor influencing reproductive effort in these two species.

If reproductive effort is calculated excluding nonreproducing females, the predictions of the stochastic model apparently were fulfilled: Palaemon adspersus invested more resources in reproduction though inhabiting the least fluctuating environment of the two. However, if some females do not reproduce at all, the average female's expectancy of its reproductive effort must include the proportion of females not reproducing. Ideally, the proportions of energy allocated to reproduction, maintenance and growth per life-time should be calculated, but this has not been possible from the present data. The proportion of non-breeders differed very much between the 2 species (Table 1 ). This cannot be explained by a different degree of reproductive hiatus between the 2 species, as in $1 \mathrm{yr}$ old females $0 \%$ of $P$. squilla and 43 to $89 \%$ of $P$. adspersus were non-reproductive. Furthermore, this great difference persisted throughout the reproductive season (Table 1; Fig. 2). Clearly, such a large and persistent difference in reproductive hiatus is unrealistic.

When non-breeding females were incorporated in the RE calculations the outcome changed: the larger and faster growing habitat specialist, Palaemon adspersus, devoted fewer resources to reproduction in a given year than the smaller habitat generalis P. squilla. On the other hand, $P$. adspersus allocates more resources to growth than $P$. squilla (Berglund, 1980), thus being able to lay larger clutches at the age of 2 yr, assuming a trade-off between resource allocation to growth vs. re-

Table 6. Intraspecific comparisons of clutch numbers per season in Palaemon adspersus (Pa) and $P$. squilla (Ps) at different ages in Kilviken Bay. Median tests

\begin{tabular}{|c|c|c|c|c|c|c|}
\hline \multirow{2}{*}{$\begin{array}{l}\text { Sampling } \\
\text { time }\end{array}$} & \multirow[t]{2}{*}{ Species } & \multirow{2}{*}{$\begin{array}{l}\text { Number of } \\
\text { clutches }\end{array}$} & \multicolumn{2}{|c|}{ Number of prawns } & \multirow[t]{2}{*}{$x^{2}$} & \multirow[t]{2}{*}{$P \leq$} \\
\hline & & & aged 1 yr & $2 \mathrm{yx}$ & & \\
\hline \multirow{4}{*}{$1981 ; 06.30-07.01$} & Ps & 1 & 24 & 2 & & \\
\hline & & 2 & 58 & 13 & .929 & n.s. \\
\hline & $\mathrm{Pa}$ & 1 & 23 & 6 & & \\
\hline & & 2 & 2 & 21 & 22.87 & .001 \\
\hline \multirow[t]{4}{*}{$1982 ; 06.21$} & Ps & 1 & 5 & 0 & & \\
\hline & & 2 & 6 & 10 & - & $.001^{\circ}$ \\
\hline & $\mathrm{Pa}$ & 1 & 4 & 25 & & \\
\hline & & 2 & 0 & 89 & $\sim$ & $.004^{\circ}$ \\
\hline \multirow[t]{4}{*}{$1982 ; 07.01$} & Ps & 1 & 3 & 0 & & \\
\hline & & 2 & 8 & 14 & - & $.072^{\circ}$ \\
\hline & $\mathrm{Pa}$ & 1 & 5 & 7 & & \\
\hline & & 2 & 7 & 95 & 10.36 & .005 \\
\hline
\end{tabular}


production (Fig. 1), P, adspersus also had fewer but larger offspring and postponed reproduction until its second year more often than $P$. squilla. Furthermore $P$. adspersus probably produced fewer clutches per year. These combinations of life history traits neatly conform with predictions from the $\mathrm{r} / \mathrm{K}$-selection theory, as $P$. adspersus inhabits less fluctuating environments than $P$. squilla. The calculations above are all based on samples of prawns living and captured together at the same time and site, so environmental conditions were identical for both species.

In both tidal sites Palaemon squilla produced heavier eggs than in the non-tidal site. At the same time numbers of offspring were the same. Still, reproductive effort did not increase in the tidal sites; obviously the eggs were not so much heavier as to significantly influence RE. However, when I compare the 2 tidal sites some interesting results emerge: where $P$. squilla inhabits the intertidal Fucus zone, and where its presumed superior competitor $P$. serratus (Pennant) is absent (Berglund, 1982), eggs were heavier and RE higher than in the site where $P$. squilla was displaced by $P$. serratus from the intertidal Fucus zone into the rockpool habitat. Thus, the presence of $P$. serratus probably affects the reproduction of $P$. squilla negatively.

Acknowledgements. I thank directors and staff of Klubban Biological Station, Fiskebäckskil, Station Biologique de Bailleron, Séné, and Laboratoire de Biologie Marine, Concarneau for hospitality and help. Drs. T. Fagerström, S. Nilsson, S. Ulfstrand, my colleagues at the section of Animal Ecology of Uppsala University and 2 anonymous referees gave valuable comments on an earlier draft. The study was supported by the Swedish Natural Science Research Council.

\section{LITERATURE CITED}

Berglund, A. (1980). Niche differentiation between two littoral prawns in Gullmar Fjord, Sweden: Palaemon adspersus and $P$. squilla. Holarct. Ecol. 3: 111-115
Berglund, A. (1981). Sex dimorphism and skewed sex ratios in the prawn species Palaemon adspersus and $P$. squilla. Oikos 36: 158-162

Berglund, A. (1982). Coexistence, size overlap and population regulation in tidal vs. non-tidal Palaemon prawns. Oecologia (Berl.) 54: 1-7

Berglund, A., Bengtsson, J. (1981). Biotic and abiotic factors determining the distribution of two prawn species: Palaemon adspersus and P. squilla. Oecologia (Berl.) 49: 300-304

Christiansen, F. B., Fenchel, T. M. (1979). Evolution of marine invertebrate reproductive patterns. Theoret. Populat. Biol. 16: $267-282$

Forster, G. R. (1951). Notes on Leander squilla L. J. mar. biol. Ass. U. K. 30: 361-367

Höglund, H. (1943). On the biology and larval development of Leander squilla (L.) forma typica de Man. Svenska Hydrografisk-Biologiska Kommissionens skr. Ny serie: Biologi II, $6: 1-44$

Jensen, J. P. (1958). Studies in the life history of the prawn Leander adspersus (Rathke) and the Danish fishery on this species. Meddr Danm. Fisk.-og Havunders. 18: 1-28

MacArthur, R. H., Wilson, E. O. (1967). Theory of island biogeography. Princeton University Press, Princeton

Menge, B. A. (1974). Effect of wave action and competition on brooding and reproductive effort in the seastar, Leptas terias hexactis. Ecology 55: 84-102

Murphy, G. I. (1968). Pattern in life history and the environment. Am. Nat. 102: 391-403

Pianka, E. R. (1970). On ' $r$ ' and ' $K$ ' selection. Am. Nat. 104: 592-597

Schaffer, W. M. (1974). Optimal reproductive effort in fluctuating environments. Am. Nat. 108: 783-790

Stearns, S. C. (1976). Life-history tactics: a review of the ideas. Q. Rev. Biol. 51: 3-47

Stearns, S. C. (1977). The evolution of life history traits; a critique of the theory and a review of the data. A. Rev. Ecol. Syst. 8: 145-171

Stearns, S. C. (1980). A new view of life-history evolution. Oikos 35: 266-281

Valentine, J. W., Ayala, F. J. (1978). Adaptive strategies in the sea. In: Battaglia, B., Beardmore, J. A. (ed.) Marine organisms. Genetics, ecology and evolution. NATO conference series, IV: Marine sciences. Plenum Press, New York, London

Zar, J. H. (1974). Biostatistical analysis. Prentice-Hall, Englewood Cliffs, N. J. 